\title{
Changes occurring in chemical composition and oxidative stability of virgin olive oil during storage
}

\author{
Esmaeil Ghanbari Shendi ${ }^{1,}$, Dilek Sivri Ozay ${ }^{1}$, Mucahit Taha Ozkaya ${ }^{2}$ and Nimeti Feyza Ustunel ${ }^{3}$ \\ ${ }^{1}$ Hacettepe University, Department of Food Engineering, Ankara 06800, Turkey \\ 2 Ankara University, Department of Horticulture, Ankara 06110, Turkey \\ ${ }^{3}$ Nar Dogal Ürünler Tur. Tic. San. A.S., Ümraniye-İstanbul, Turkey
}

Received 13 July 2018 - Accepted 11 September 2018

\begin{abstract}
In present study, "Saurani" Turkish olive monocultivar extra virgin olive oil (EVOO) was extracted by using Mobile Olive Oil Processing Unit (MOOPU)" (TEM Oliomio 500-2GV, Italy). Free fatty acid content, peroxide value, moisture content and UV absorbance value, minor and major components and quality characteristics changes were surveyed during a year storage. "Saurani" olive oil samples weren't categorized as EVOO according to the trade standards of International Olive Council (IOC) based on peroxide value, UV absorbance values after five and two months of storing, respectively. Free fatty acid content of VOO samples increased during 12 months' storage, but it was under the IOC limitation for extra virgin olive oil $(<0.8 \%)$. According to the results, color values of VOO changed from green to yellow while UV absorbance values altered during storage. Total phenol content decreased from 342.95 to $252.42 \mathrm{ppm}$ in EVOO samples during a year storage time. Luteolin was the most abundant phenolic compound and its decrement was $10 \%$. Tyrosol content of VOO samples increased from 2.80 to $8.81 \mathrm{ppm}$. Except tyrosol, other phenolic compounds' concentration decreased after a year storage time. $\alpha$-tocopherol contents of VOO sample were $324.60 \mathrm{ppm}$. After 12 months of storage, about $20.48 \%$ of $\alpha$-tocopherol content was destroyed. Amounts of phenolic and tocopherol isomers decreased during storage as expected. Results of this study showed that chemical composition and oxidative stability of VOO samples changed significantly.
\end{abstract}

Keywords: olive oil / saurani / phenolic compounds / tocopherol / storage

Résumé - Modifications de la composition chimique et de la stabilité à l'oxydation de l'huile d'olive vierge pendant le stockage. Dans cette étude, l'huile d'olive turque extra vierge (EVOO) monocultivar «Saurani» était extraite à l'aide d'une unité mobile de traitement de l'huile d'olive (TEM Oliomio 500-2GV, Italie). La teneur en acides gras libres, l'indice de peroxyde, la teneur en eau et l'absorbance UV, les composants mineurs et les changements des caractéristiques de qualité ont été étudiés pendant une année de stockage. Les échantillons d'huile d'olive «Saurani»n'ont pas été classés comme EVOO conformément aux normes commerciales du Conseil oléicole international (COI) fondées sur l'indice de peroxyde, l'absorbance UV après cinq et deux mois de stockage, respectivement. La teneur en acides gras libres des échantillons de VOO a augmenté pendant les 12 mois de stockage, mais restait inférieure à la limite du COI pour l'huile d'olive vierge extra $(<0,8 \%)$. Selon les résultats, les valeurs de couleur de VOO sont passées du vert au jaune, tandis que les valeurs d'absorbance UV ont été altérées pendant le stockage. La teneur totale en phénols a diminué de 342,95 à 252,42 ppm dans les échantillons EVOO durant l'année de stockage. La lutéoline était le composé phénolique le plus abondant dont la baisse a atteint $10 \%$. La teneur en tyrosol des échantillons de $\mathrm{VOO}$ a augmenté de 2,80 à $8,81 \mathrm{ppm}$. À l'exception du tyrosol, la concentration des autres composés phénoliques diminue après un an de stockage. La teneur en $\alpha$-tocophérol de l'échantillon VOO était de 324,60 ppm. Après 12 mois de stockage, $20,5 \%$ de la teneur en $\alpha$-tocophérol est détruite. Les quantités d'isomères phénoliques et de tocophérols diminuent pendant le stockage comme prévu. Les résultats de cette étude soulignent que la composition chimique et la stabilité à l'oxydation des échantillons de VOO ont changé de manière significative.

Mots clés : huile d'olive / variété Saurani / composés phénoliques / tocophérols / stockage

*Correspondence: esi.1361@gmail.com 


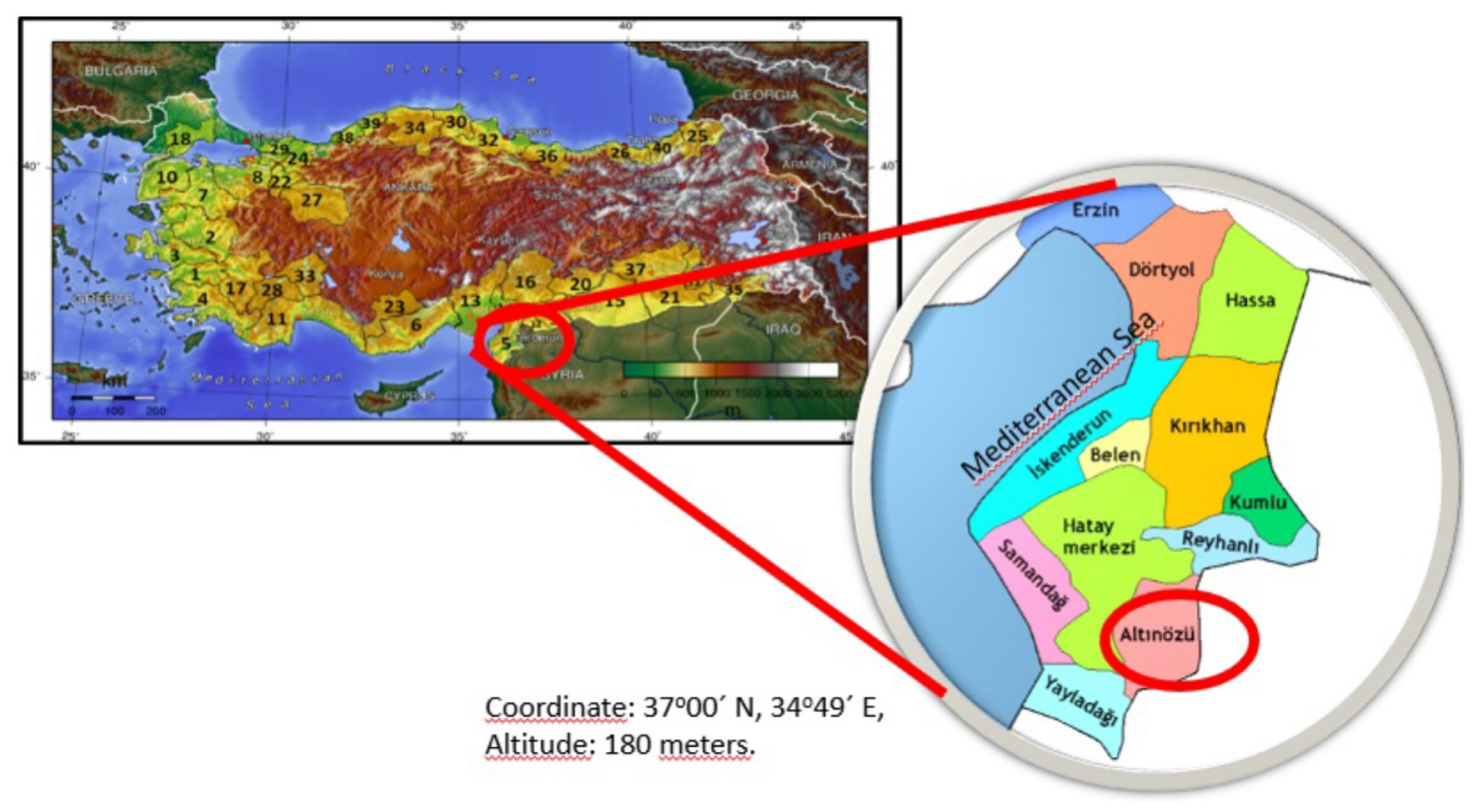

Fig. 1. Map of Hatay province.

\section{Introduction}

Extra virgin olive oil (EVOO), an excellent natural and functional food, is obtained from olive fruits by using mechanical or physical procedures. Saurani is a domestic variety in the Hatay province of the south of Turkey. Altınözü is one of the districts of Hatay Province, located in Eastern Mediterranea region. The origin of "Saurani" olive cultivar is Altınözü-Hatay (Fig. 1). An abundance of oleic acid, a monounsaturated fatty acid, linoleic and linolenic acids as polyunsaturated fatty acids, are the characteristics that sets olive oil apart from other vegetable oils. From the ancient times, people of Mediterranean countries consume extra virgin olive oil (EVOO). Phenolic compounds, vitamins, high oleic content and other minor compounds made olive oil unique among other edible oils. EVOO's composition varies widely, depending on cultivar, ripeness degree, ecologic conditions, growing region, processing techniques and storage. Presence of antioxidants such as mainly polar phenols and $\alpha$-tocopherol made its shelf life longer than other edible oils. Oxidative stability is affected negatively by other factors such as free fatty acids, unsaturated hydrocarbons, enzymes, and trace metals. Pigments have negative effect on oxidative stability. Storage of olive oil under nitrogen pressure in a dark place at room temperature $\left(25-30^{\circ} \mathrm{C}\right.$ or lower) increases shelf life (Boskou, 2006). EVOO's major and minor components as well as oxidation indices of virgin olive oil were changed during storage. Oxidative stability parameters such as, free fatty acidity, peroxide value and oxidative rancidity increased during storing time. Total polyphenols declined up to $73 \%$, and this decrease was remarkable higher in samples whose initial phenol contents were greater. Another important factor in olive oil quality is storage conditions. Amounts of tyrosol and hydroxytyrosol had no change during storage at room temperatures. There was no change in aromatic hydrocarbons of freezed samples up to 12 months (Mulinacci et al., 2013). Unsaturated fatty acid composition had no significant changes (Rastrelli et al., 2002; Méndez and Falqué, 2007). Other researchers reported that fatty acid composition remained constant up to three months, but unsaturation's degree and oleic acid content decreased at the end of storing time. Seventy-nine percent of $\alpha$-tocopherol (vitamin E) was destroyed in four months, whereas $<45 \%$ of the phenols was lost under diffused light during storage (Okogeri and Tasioula-Margari, 2002). The age of the oils and the tyrosol to total phenols ratio showed a positive correlation (Cinquanta et al., 1997). EVOO with high antioxidant contents were still "excellent" after 240 days of storage at $40^{\circ} \mathrm{C}$ (Lavelli et al., 2006). Important losses of chlorophyll, carotenoids, and total phenol contents of a commercial virgin olive oil extracted Arbequina cultivar were reported after 12 months of storage. Morelló et al. (2004) reported that oleic acid percentage of EVOO was increased during storage time. Psomiadou et al. (2000) suggested a good handling is quite important for retaining high $\alpha$-tocopherol levels of Greek VOO under domestic conditions up to two years.

Significant loss of hydroxytyrosol was observed in filtration of eight virgin olive oil through cotton in the laboratory (Bendini et al., 2009). On the other hand, Fregapane et al. (2006) reported that filtration and especially dehydration could help prolong the shelf life of some high quality but less stable virgin olive oils. Phenolic compounds, tocopherols, pigments, fatty acid profiles, and antioxidant activity of monovarietal virgin olive oil from five different Turkish varieties (Egriburun, Karamani, Halhalı, Saurani and Hasebi) from Hatay province on three different occasions have been analyzed. The high total phenolic, secoiridoid, aglycones, $\alpha$-tocopherol and antioxidant activity of Saurani variety makes the oil of this variety superior to other varieties analyzed in this study (Arslan and Schreiner, 2012).

In this research a MOOPU was designed to produce "monovarietal boutique virgin olive oil" and used for olive oil production from "Saurani" cultivar.

The number of olive trees of Saurani cvs. is about 500000 . Most of the trees are older than 300 years. Total yield is about 70000 tons per year. The alternate bearing is strong level. The 


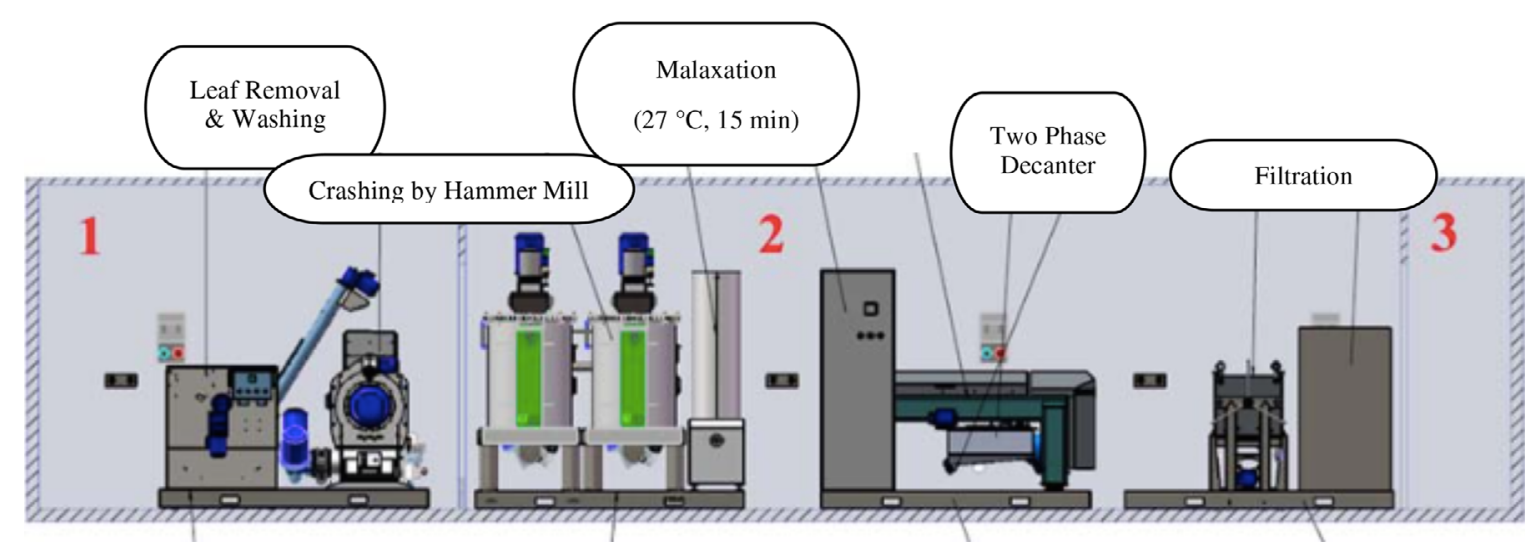

Fig. 2. Mobile olive oil processing unit (mill on wheel).

local growers are used mainly for olive oil and some for green and black table olive but for local consumption. While early harvesting fruit has $15 \%$ olive oil, at the end of ripening it increased up to $25 \%$ level (Ozkaya, 2016). MOOPU was transferred into the orchard located in Hatay region of the south of Turkey. Therefore, it was possible to obtain premium olive oil at optimum conditions within two hours after harvest. Olive oils were packaged and quality parameters were monitored during storage monthly for 12 months.

\section{Methods and materials}

\subsection{Production of extra virgin olive oil (EVOO)}

MOOPU with state-of-the art Olemio equipment was designed in order to produce VOO (Fig. 2). A special container was constructed and equipped with a knife crusher and a twophase horizontal decanter (Oliomio D500, Italy). The mobile unit is an articulated lorry with a special semi-trailer measuring $2438 \times 12192 \times 2896 \mathrm{~mm}$ which is divided into three separate sections. First section is olive accepting unit including; bunker, leaf removers, washer and crusher units of the system. Second section is processing unit including malaxer, decanter, filter and bag-in-box filling machine. Third section is support unit including power plant and a water supply tank. Processing unit was equipped by an air conditioner, isolation and filter ventilation systems and protected for temperature changes, dust and odor. MOOPU carried by a trailer truck to orchards in 2015-2016 season. Olive fruits were harvested by hand picking in the early harvest period and processed to "cold press" VOO in the MOOPU in a few hours. Olive paste was prepared after crushing by a hammer mill and the paste was mixed in the malaxer at $27^{\circ} \mathrm{C}$ for $15 \mathrm{~min}$ (cold press). After decantation VOO was filtered and filled in $250 \mathrm{~mL}$ amber glass bottles (headspace: $4 \mathrm{~cm}$ ) by nitrogen gas. The bottles were stored at room temperature $\left(18-24^{\circ} \mathrm{C}\right)$ up to 12 months.

\subsection{Chemical analysis}

Chemical analysis including, free fatty acid content, peroxide value, moisture was performed according to the EC 2568/91, AOCS Cd 8-53 methods, ISO 66 respectively. Color values ( $L, a, b$ values) were measured by spectrophotometer (Minolta, CM-3600d, Japan). L (lightness), b (yellowness), and $a$ (redness) values were determined. UV absorbance was performed according the IOC method COI/T.20/Doc. No. 19/ Rev. 3 (Anonymous, 2010; International Olive Council, 2015b). UV absorbance was collected in 232, 266, 270 and $274 \mathrm{~nm}$ by using UV Spectrophotometer (Agilent 8453, USA). $\Delta \mathrm{K}$ values were calculated with the following formula:

$$
\Delta \mathrm{K}=\mathrm{K}_{270}-\left[\left(\mathrm{K}_{266}+\mathrm{K}_{274}\right) / 2\right] \text {. }
$$

\subsection{Total phenolic content}

Polar fraction was extracted and used for total phenolic and phenolic composition analyses. Olive oil sample $(2.5 \mathrm{~g})$ was weighed into a falcon tube. Hexane $(6 \mathrm{~mL})$ was added and shaken for $1 \mathrm{~min}$. This solution was filtered through solid phase extraction (SPE) cartridge (Superclean LC-Diol, USA) and collected in a glass tube. Then hexane $(6 \mathrm{~mL})$ and $4 \mathrm{~mL}$ hexane: ethyl acetate $(85: 15, \mathrm{v} / \mathrm{v})$ were passed through the SPE cartridge, respectively. The cartridge was washed with methanol:deionized water solution $(1: 1 \mathrm{v} / \mathrm{v})$ and phenolic extract was evaporated (UniEquip Univapo $100 \mathrm{ECH}$, Canada). After addition of $2 \mathrm{~mL}$ methanol:deionized water solution $(1: 1 \mathrm{v} / \mathrm{v})$ the tubes were vortexed for 30 second. For determination of total phenols Folin $\&$ Ciocalteu method was used and the results were expressed in terms of gallic acid equivalent (mg gallic acid/kg oil) (Romani et al., 2007; Inarejos-Garcia et al., 2009). Ultra high performance liquid chromatography (UHPLC, Thermo Scientific Dionex Ultimate 3000 , USA) and C18 column (4.6 mm inner diameter $\times 250 \mathrm{~mm}$ length and $5 \mathrm{~mm}$ particle diameter; Thermo scientific acclaim 120) was used for determination of phenolic profile. Prepared phenolic extract $(1 \mathrm{~mL})$ was passed through $0.45 \mu \mathrm{m}$ microfilter (Merck, PVDF, Millipore Millex-HV, Germany) and poured into an amber vial. Column temperature was fixed at $30^{\circ} \mathrm{C}$ and acetic acid:deionized water (1:1) (A), methanol (B), acetonitril $(\mathrm{C})$ were used in a gradient flow program as mobile phase. In the gradient program eluents were $2.5 \% \mathrm{~B}, 2.5 \% \mathrm{C}$, and $95 \%$ A solution up to $60 \mathrm{~min}$. Flow rate was $1 \mathrm{~mL} / \mathrm{min}$ and diode array detector (DAD) detector was set in $280 \mathrm{~nm}, 320 \mathrm{~nm}$ and $335 \mathrm{~nm}$. Apigenin, cafeic acid, gallic acid, luteolin, m-cumaric acid, p-coumaric acid, oleuropein, syringic acid, trans-ferulic acid, vanilic acid, vanillin, tyrosol, 3-hydroxy tyrosol, 3.4dihydroxy benzoic acid, 4-hydroxy benzoic acid, 4-hydroxy phenyl acetic acid were used as standards. 
E. Ghanbari Shendi et al.: OCL 2018, 25(6), A602

Table 1. Oxidative stability parameters and color valuse of Saurani extra virgin olive oils during 12 months storage.

\begin{tabular}{|c|c|c|c|c|c|c|c|}
\hline $\begin{array}{l}\text { Storage } \\
\text { period (month) }\end{array}$ & $\begin{array}{l}\text { Free fatty acid } \\
\text { content }(\%)\end{array}$ & $\begin{array}{l}\text { Peroxide } \\
\text { value }\left(\mathrm{meqO}_{2} / \mathrm{kg} \text { yag }\right)\end{array}$ & $\mathrm{K}_{232}$ & $\mathrm{~K}_{270}$ & $L$ value & $a$ value & $b$ value \\
\hline 0 & $0.3 \pm 0.03^{\mathrm{d}}$ & $17.9 \pm 0.04^{\mathrm{g}}$ & $1.9 \pm 0.00^{\mathrm{h}}$ & $0.15 \pm 0.00^{\mathrm{h}}$ & $31.3 \pm 0.10^{\mathrm{ab}}$ & $1.8 \pm 0.03^{\mathrm{de}}$ & $6.3 \pm 0.45^{\mathrm{b}}$ \\
\hline 2 & $0.5 \pm 0.00^{\mathrm{b}}$ & $18.1 \pm 0.09^{\mathrm{f}}$ & $0.4 \pm 0.00^{\mathrm{j}}$ & $0.99 \pm 0.00^{\mathrm{a}}$ & $31.8 \pm 0.04^{\mathrm{ab}}$ & $2.0 \pm 0.02^{\text {cde }}$ & $6.6 \pm 0.06^{\mathrm{ab}}$ \\
\hline 3 & $0.5 \pm 0.03^{b}$ & $18.5 \pm 0.11^{\mathrm{e}}$ & $0.4 \pm 0.00^{\mathrm{j}}$ & $0.35 \pm 0.00^{\mathrm{c}}$ & $31.9 \pm 0.01^{\mathrm{ab}}$ & $2.0 \pm 0.01^{\text {bcde }}$ & $6.6 \pm 0.19^{\mathrm{ab}}$ \\
\hline 6 & $0.5 \pm 0.00^{\mathrm{b}}$ & $23.5 \pm 0.02^{\mathrm{b}}$ & $2.2 \pm 0.00^{\mathrm{e}}$ & $0.16 \pm 0.00^{\mathrm{g}}$ & $32.2 \pm 0.07^{\mathrm{a}}$ & $2.3 \pm 0.00^{\mathrm{ab}}$ & $7.8 \pm 0.10^{\mathrm{ab}}$ \\
\hline 7 & $0.5 \pm 0.00^{\mathrm{b}}$ & $26.6 \pm 0.05^{\mathrm{a}}$ & $3.4 \pm 0.00^{\mathrm{a}}$ & $0.40 \pm 0.00^{\mathrm{b}}$ & $32.1 \pm 0.26^{\mathrm{a}}$ & $2.4 \pm 0.00^{\mathrm{a}}$ & $7.6 \pm 0.50^{\mathrm{ab}}$ \\
\hline 8 & $0.5 \pm 0.00^{\mathrm{b}}$ & $17.9 \pm 0.06^{\mathrm{g}}$ & $2.0 \pm 0.00^{\mathrm{g}}$ & $0.22 \pm 0.00^{\mathrm{e}}$ & $31.8 \pm 0.60^{\mathrm{ab}}$ & $2.3 \pm 0.04^{\mathrm{abc}}$ & $7.9 \pm 0.31^{\mathrm{a}}$ \\
\hline 9 & $0.6 \pm 0.00^{\mathrm{a}}$ & $15.6 \pm 0.04^{\mathrm{h}}$ & $2.1 \pm 0.00^{\mathrm{f}}$ & $0.13 \pm 0.00^{\mathrm{j}}$ & $31.6 \pm 0.86^{\mathrm{ab}}$ & $2.2 \pm 0.10^{\mathrm{abc}}$ & $6.7 \pm 1.30^{\mathrm{ab}}$ \\
\hline 10 & $0.6 \pm 0.00^{\mathrm{a}}$ & $13.9 \pm 0.01^{\mathrm{i}}$ & $2.4 \pm 0.00^{\mathrm{c}}$ & $0.30 \pm 0.00^{\mathrm{d}}$ & $29.8 \pm 1.17^{\mathrm{c}}$ & $1.5 \pm 0.20^{\mathrm{f}}$ & $3.5 \pm 1.74^{\mathrm{c}}$ \\
\hline
\end{tabular}

${ }^{*}$ Different superscript letters in the same column indicate significant difference between mean values $(P<0.01)$.

$N=28$.

\subsection{Tocopherol composition}

Tocopherol composition was determined by using AOCS Official Method Ce 8-89, 1997. Two grams EVOO sample was weighed into a $25 \mathrm{~mL}$ volumetric flask. A quantity of hexane was used for dissolving of oil, and then flask was made up to volume. Solution was passed from syringe filter $(0.45 \mu \mathrm{m})$ (PVDF, Millipore Millex-HV) into the HPLC vial. The samples $(20 \mu \mathrm{L})$ injected to HPLC (UHPLC: Ultra High Performance Liquid Chromatography (Dionex Ultimate 3000). LiChrosorb SI 605 column $(4.6 \mathrm{~mm}$ I.D $\times 250 \mathrm{~mm}$ length and $5 \mu \mathrm{m}$ particle size) was used for analysis. Column temperature was fixed at $30^{\circ} \mathrm{C}$ during process. Flow rate of analysis was $1 \mathrm{~mL} / \mathrm{min}$. Isopropanol:hexane $(0.5: 99.5, \mathrm{v} / \mathrm{v})$ isocratic mix was used for mobile phase, and chromatograms were obtained at $292 \mathrm{~nm}$ wavelength. Analysis time and injection volume were $30 \mathrm{~min}$ and $100 \mu \mathrm{L}$, respectively. Tocopherol standards were used for determination of $\alpha, \beta$, $\mathrm{\gamma}$ and $\Delta$ tocopherols.

\subsection{Sensory analysis}

Every month, olive oil samples were evaluated by the Ayvalık Olive Oil Tasting Laboratory accredited by International Olive Council and TURKAK (Turkish Accreditation Agency) according to the method for the organoleptic assessment of virgin olive oil (International Olive Council, 2015a). Eight trained tasting panels were able to assess the oils to determine the levels of positive attributes, such as fruitiness, bitterness and pungency. Negative attributes arising due to poor quality fruit, incorrect processing or storaging, such as rancidity, musty and fusty, were determined by sensory panels. Descriptors were evaluated on a $0-10$ intensity scale (a number between 0 and 10).

\subsection{Statistical analysis}

Statistical analysis was performed by SPSS 17 (SPSS Inc. Chicago, IL) statistical software and using One-way Anova method. All analyses were performed at least duplicate and differences among all groups were determined by Duncan test.

\section{Results}

\subsection{Chemical analyses}

Free acidity, peroxide and UV absorbance values of the olive oils produced in the MOOPU were shown in Table 1. Saurani were not classified as extra virgin olive oil after five month storing according to the results of peroxide value and UV absorbance (International Olive Oil Council standards).

Free fatty acid content of EVOO samples of Saurani (Hatay) showed increasing trend during a year of storage time (Tab. 1). Sharp increases were observed in first, second and ninth months of storing. The results showed that free acidity of EVOOs had significant differences during a year storage period $(P>0.01)$. Some researchers showed that free acidity increased with storage depending on the packaging material, storage conditions and time (Lavelli et al., 2006; Clodoveo et al., 2007; Méndez and Falqué, 2007; Baiano et al., 2014).

Peroxide values (PV) of VOOs showed increasing trend during early stages of storing (Tab. 1). It was higher than IOC limitation after fifth month. The PV reached to maximum values in seventh month. There was significant difference among VOOs peroxide value during a year storage time $(P<0.01)$. Significant increases were reported on the PV of olive oil samples during short-term (30 days) and long-term (sixth years) of storage in different packaging materials at different conditions (Okogeri and Tasioula-Margari, 2002; Lavelli et al., 2006; Clodoveo et al., 2007; Baiano et al., 2014).

UV absorbance values (K232 and K270) which are indicator of oxidation changed during storage significantly (Tab. 1). K232 value of Saurani (Hatay) VOO decreased up to fourth month. It increased up to eighth month. Maximum 
K232 was observed in seventh month. K232 value of VOOs decreased in eighth month. This value showed slowly increase near to end of storage period. Generally, there were significant differences among all VOOs during storage $(P<0.01)$.

Saurani (Hatay) VOO had the highest and the lowest value of $\mathrm{K} 270$ values in second and first months, respectively (Tab. 1). K270 value of Saurani VOOs was higher than IOC limitation in second, third, fifth, seventh, eighth and tenth months. $\Delta \mathrm{K}$ values of filtered and unfiltered samples were zero or below zero (results are not shown). These results are in agreement in the related literature (Okogeri and Tasioula-Margari, 2002; Caponio et al., 2005; Del Caro et al., 2006; Lavelli et al., 2006; Gómez-Alonso et al., 2007; Méndez and Falqué, 2007; Baiano et al., 2014). Baiano et al. (2014) reported that K232 value of Coratina olive oil increased up to sixth year, then it decreased, at the end of final storage an increase was observed. Gutiérrez and Fernández (2002) showed that only two quality indices (K270 and sensory evaluation) Picual and Hojiblanca olive oils decreased during storage at $2{ }^{\circ} \mathrm{C}$ in darkness and $30^{\circ} \mathrm{C}$ in illimunation. Quality deterioration resulted in downgraded olive oils which was no longer extra virgin olive oils during storage and there was an excellent correlation between initial stability and the time to reach the limit of $\mathrm{K} 270>0.25$.

\subsection{Color analysis}

In spite of the fact that color is not regarded as an important quality characteristic for extra virgin olive oils, it has a great effect on consumer acceptance. Color of virgin olive oils is related to olive maturity and process conditions. Analysis of color ( $L, a$ and $b$ values) showed that color of olive oil samples altered significantly during storage (Tab. 1). It has been attributed to decomposition of color pigments such as chlorophylls, pheophytins, xanthophylls and carotenes (Boskou, 2006). The lowest $L$ values (lightness) were seen in tenth month for VOO samples. The highest $L$ values were observed in sixth and seventh months. Fluctuations were observed in $a$ (redness) and $b$ (yellowness) values of all samples during storage. The highest $b$ value were obtained for eighth month. After this month, there was a decreasing trend in $b$ values of VOO samples, but $b$ value increased at the end of storage time.

\subsection{Tocopherol profile}

Tocopherol $(\alpha, \beta, \gamma)$ profile of Saurani EVOO was determined during storage time (Tab. 2). The results showed that tocopherol contents $(\alpha, \beta, \gamma)$ decreased with increasing storage time as expected. The lowest tocopherol contents were obtained after a year of storage. It means that $20.48 \%$ of $\alpha$-tocopherol, $89.47 \%$ of $\beta$-tocopherol and $33.33 \%$ of $\gamma-$ tocopherol contents were decomposed in VOO samples during storage. These results were in agreement with other researcher results (Psomiadou et al., 2000; Okogeri and Tasioula-Margari, 2002; Rastrelli et al., 2002; Baiano et al., 2014).
Table 2. Tocopherol content of Saurani (Hatay) monocultivar during 12 months' storage (ppm).

\begin{tabular}{llll}
\hline $\begin{array}{l}\text { Storage period } \\
\text { (month) }\end{array}$ & $\alpha$-tocophero & $\beta$-tocopherol & $\gamma$-tocopherol \\
\hline 0 & $324.6 \pm 0.75^{\mathrm{a}}$ & $1.9 \pm 0.02^{\mathrm{a}}$ & $0.2 \pm 0.00^{\mathrm{a}}$ \\
3 & $276.9 \pm 1.73^{\mathrm{b}}$ & $1.5 \pm 0.00^{\mathrm{b}}$ & $0.1 \pm 0.00^{\mathrm{b}}$ \\
6 & $272.1 \pm 0.80^{\mathrm{c}}$ & $1.5 \pm 0.00^{\mathrm{b}}$ & $0.1 \pm 0.00^{\mathrm{b}}$ \\
12 & $258.1 \pm 1.10^{\mathrm{d}}$ & $0.2 \pm 0.00^{\mathrm{c}}$ & $0.1 \pm 0.00^{\mathrm{b}}$ \\
\hline
\end{tabular}

*Different superscript letters in the same column indicate significant difference between mean values $(P<0.01)$.

$N=28$.

Table 3. Changes in total phenols of Saurani EVOOs during 12 months of storage (ppm).

\begin{tabular}{ll}
\hline $\begin{array}{l}\text { Storage } \\
\text { period (month) }\end{array}$ & Saurani EVOOs \\
\hline 0 & $343.0 \pm 0.22^{\mathrm{a}}$ \\
3 & $324.6 \pm 0.76^{\mathrm{b}}$ \\
6 & $307.7 \pm 0.81^{\mathrm{c}}$ \\
9 & $272.3 \pm 0.46^{\mathrm{d}}$ \\
12 & $252.4 \pm 0.35^{\mathrm{e}}$
\end{tabular}

*Different superscript letters in the same column indicate significant difference between mean values $(P<0.01)$. $N=28$.

\subsection{Total polyphenol}

Total polyphenols contents of the samples were presented in Table 3. The highest total polyphenol values were determined at fresh oils and its amount decreased with time. But the decreases were not dramatic, after a year $26.39 \%$ of total polyphenols were decomposed VOO samples. Using MOOPU and optimum storage condition helped to protect VOOs polyphenols. After a short-term or long-term storage significant decreases in total polyphenols were reported for monocultivar and commercial olive oils by Morelló et al. (2004), Clodoveo et al. (2007), Abdalla et al. (2014) and Baiano et al. (2014).

\subsection{Phenolic profiles}

Phenolic compounds assay was performed during storage time for VOO samples. The results of phenolic profiles are shown in Table 4. 3,4-dihydroxy benzoic acid concentration was $9.82 \mathrm{ppm}$ in zeroth month of storage. Its amount decreased to $3.70 \mathrm{ppm}$ at the end of storage period. The initial concentration of tyrosol was $2.80 \mathrm{ppm}$. Tyrosol content of VOOs increased to $8.81 \mathrm{ppm}$ after 12 months storing. 4hydroxy benzoic acid had a decline trend from zeroth month up to end of storage (3.94 to $3.23 \mathrm{ppm})$. m-coumaric acid was found in $3.07 \mathrm{ppm}$ at the beginning of storage time. At the end of storage period, this value was $1.69 \mathrm{ppm}$. o-coumaric content changed from 4.88 to $2.28 \mathrm{ppm}$ during storage period. 
Table 4. Changes in phenolic compounds of Saurani (Hatay) during 12 months of storage time (ppm).

\begin{tabular}{lrrr}
\hline & & Month & \\
\hline Phenolic Compounds & 0 & 6 & 12 \\
3,4-dihydroxy benzoic acid & $9.8 \pm 0.04^{\mathrm{a}}$ & $7.8 \pm 0.10^{\mathrm{b}}$ & $3.7 \pm 0.00^{\mathrm{c}}$ \\
Tyrosol & $2.8 \pm 0.04^{\mathrm{c}}$ & $5.2 \pm 0.00^{\mathrm{b}}$ & $3.8 \pm 0.17^{\mathrm{a}}$ \\
4-hydroxy benzoic acid & $3.9 \pm 0.02^{\mathrm{a}}$ & $3.4 \pm 0.00^{\mathrm{b}}$ & $3.2 \pm 0.02^{\mathrm{c}}$ \\
m-coumaric acid & $3.0 \pm 0.10^{\mathrm{a}}$ & $3.2 \pm 0.00^{\mathrm{b}}$ & $1.7 \pm 0.05^{\mathrm{c}}$ \\
o-coumaric acid & $4.9 \pm 0.04^{\mathrm{a}}$ & $5.2 \pm 0.00^{\mathrm{b}}$ & $2.3 \pm 0.05^{\mathrm{c}}$ \\
Oleuropein & $5.4 \pm 0.04^{\mathrm{a}}$ & $211.2 \pm 0.90^{\mathrm{b}}$ & \\
Luteolin & $222.6 \pm 0.40^{\mathrm{a}}$ & $10.7 \pm 0.15^{\mathrm{b}}$ & $200.4 \pm 1.90^{\mathrm{c}}$ \\
Apigenin & $12.5 \pm 0.34^{\mathrm{a}}$ & $6.1 \pm 0.13^{\mathrm{c}}$ \\
\hline
\end{tabular}

*Different superscript letters in the same raw indicate significant difference between mean values $(P<0.01)$.

nd: not detected.

$N=28$.

Oleuropein content of Saurani (Hatay) VOOs was $5.41 \mathrm{ppm}$ in the zeroth month. It reached to minimum level $(4.93 \mathrm{ppm})$ at the end of storing. Luteolin was abundant polyphenol among all phenolic compounds. The initial concentration of luteolin was $222.58 \mathrm{ppm}$ in zeroth month. Its amount decreased to 200.38 ppm during storage period significantly. Apigenin was detected in $12.46 \mathrm{ppm}$ in zeroth month. After 12 months storing, apigenin content decreased $6.11 \mathrm{ppm}$.

These results confirmed that storage caused to significant changes on the phenolic profile. It is widely recognized that the simple phenols, tyrosol and hydroxytyrosol increase over time due to hydrolytic processes of the secoiridoidic derivatives representing their linked forms (Mulinacci et al., 2013). Yorulmaz (2009) reported that luteolin was the most abundant phenolic compound following trans-cinnamic acid and luteolin7-glucoside. They also quantified tyrosol, syringic acid, pcoumaric acid, luteolin-7-glucoside, trans cinnamic acid, luteolin and apigenin in Turkish olive oils extracted from different olive varieties. Montedoro et al. (1992) reported that 3,4-DHPEA, $p$-HPEA, vanilic acid, cafeic acid, 3,4-DHPEAEDA, 3,4-DHPEA-EA had been identified in olive oils. Morelló et al. (2004) suggested that although storage did not appear to have any effect on vanilic acid or vanillin, which were present at low concentration there was a significant decrease in the concentration of the rest of the quantified phenolic compounds. That reduction was more marked in the secoiridoid derivatives such as 3,4-DHPEA-EDA, p-HPEA-EDA and 3,4-DHPEA-EA indicating a more active participation in the oxidative processes as they were more easily oxidized. Among the most representative phenolic compounds in olive oil, lignans seem to be the most stable during oil storage. Mulinacci et al. (2013), Gómez-Alonso et al. (2007) and García et al. (2003) showed an increase tyrosol and hydroxytyrosol contents over time due to hydrolytic processes of the secoiridoidic derivatives. Arslan and Schreiner (2012) showed that Saurani was superior cultivar among five different Turkish cultivars due to high total phenolics, secoiridoid aglycones, $\alpha$-tocopherol and antioxidant activity. Gómez-Alonso et al. (2007) stated that the main phenols were the dialdehydic form of elenolic acid linked to tyrosol (p-HPEA-EDA;), oleuropein aglycon, and the dialdehydic form of elenolic acid linked to hydroxytyrosol (3,4-DHPEA-EDA; ppm). Baiano et al. (2014) reported that there were increasing

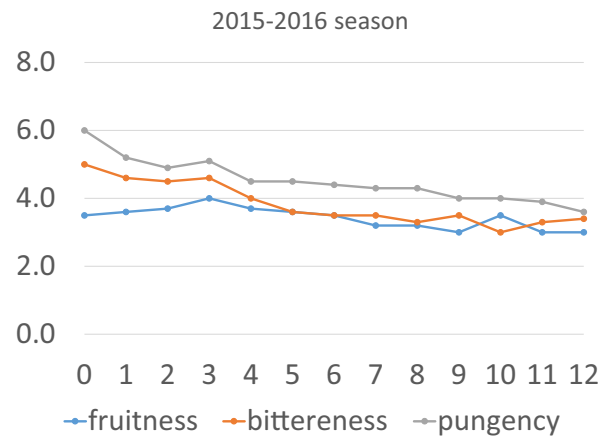

Fig. 3. Sensory values of Saurani (Hatay) olive oils during 12 months of storage.

and decreasing trends in phenolic compounds (3,4-DHPEA, $p$-HPEA, vanillin, $p$-coumaric acid, 3,4-DHPEA-AC, 3, 4-DHPEA-EDA, $p$-HPEA-AC, $p$-HPEA-EDA, 1-acetoxipinoresinol + trans-cinnamic acid, $p$-HPEA-EA) content.

\subsection{Sensory analysis}

In both filtered and unfiltered EVOO, Pungency was higher than fruitness and bitterness. The difference between 0 to 12 month is about 2 points for pungency but 1 point for fruitiness and bitterness (Fig. 3). This variety has stabile olive oil so the flavor is protected whole year even in the room temperature.

The oil-rich fruits of the Saurani olive tree are used to make olive oil, as well as black and green table olives. Characterized by medium hardness, the fruits of the Saurani olive tree are small, abundant and cold-resistant. With the addition of Special for the Connoisseur Hatay Saurani Extra Virgin Olive Oil, the series now boast five products. With its unique flavour and lasting feeling of freshness, Special for the Connoisseur Hatay Saurani Extra Virgin Olive Oil is enriching breakfasts, as well as cold dishes, creating a difference with its fruitiness and spiciness. Bitter and piquant to the tongue and palate, Special for the Connoisseur Hatay Saurani Extra Virgin Olive Oil is of high quality. 


\section{Conclusion}

In this project, MOOPU (TEM Oliomio 500-2GV, Italy) was used for extraction of EVOO from Turkish Saurani olive cultivar. The aim of study was production of extra virgin olive oil with premium quality. The project reached this goal. Extracted EVOO by MOOPU had high quality in terms of physicochemical properties. On the other hand, Saurani is one of the famous olive cultivar in south region of Turkey. In spite of some limited research paper about Saurani EVOO in the literature, there is no research about its behavior during storage time, therefore this project can be useful for determination of its physical and chemical features during 12 months' storage. The effects of storage time for 12 months on the chemical properties such as free acidity, peroxide value, color, UV absorbance, tocopherol content, total phenols, and phenolic compounds of monocultivar virgin olive oils (VOOs) extracted from some Saurani (Hatay) produced in a MOOPU were investigated in present project. According to the results, oxidative stability parameters of Saurani EVOOs increased during storage time and Saurani was classified in virgin olive oil category. This may be related to olive fly (Bactrocera oleae) which was common disease in Hatay province in 2015-2016 harvest season. Saurani virgin olive oil (VOO) showed wide range of phenolic compounds and high content of tocopherol isomers. So, this study discloses nutraceutical and functional effects of Saurani. According to chemical results, it can be said that total phenol, phenolic compounds, and tocopherol isomers of Saurani (Hatay) monocultivar VOOs were decreased. So it is better that VOOs consume in early stages of storing. Present research, disclose some important and effective properties of Saurani EVOO for improving of Olive oil production and programming in Turkey.

\section{Abbreviation}

$\begin{array}{ll}\text { EVOO } & \text { Extra virgin olive oil } \\ \text { VOO } & \text { Virgin olive oil } \\ \text { IOC } & \text { International Olive Council } \\ \text { MOOPU } & \text { Mobile Olive Oil Processing Unit }\end{array}$

Acknowledgment. The authors are also grateful for the financial supports that were provided by Republic of Turkey, Ministry of Science, Industry and Technology for financial supports of SANTEZ- 0560-STZ-2013-2 project.

\section{References}

Abdalla IIH, Khaddor M, Boussab A, Garrouj DEl, Ayadi M. 2014. The effect of storage time on the quality of olive oil produced by cooperatives for olive growers in the north of Morocco. Asian $J$ Agric Food Sci 02: 129-138.

American Oil Chemists' Society (AOCS). 1997. AOCS Official method Ce 8-89. Determination of tocopherols and tocotrienols in vegetable oils and fats by HPLC.

American Oil Chemists' Society (AOCS). 2003. Cd 8-53. Official method for determining peroxide value acetic acid-chloroform.

Anonymous. 2010. The official gazette of Republic of Turkey, Number 27665. Ankara (Turkey).
Arslan D, Schreiner M. 2012. Chemical characteristics and antioxidant activity of olive oils from Turkish varieties grown in Hatay province. Sci Hortic 144: 141-152. https://doi.org/ 10.1016/j.scienta.2012.07.006.

Baiano A, Terracone C, Viggiani I, Del Nobile MA. 2014. Changes produced in extra-virgin olive oils from cv. Coratina during a prolonged storage treatment. Czech J Food Sci 32(1): 1-9.

Bendini A, Cerretani L, Salvador MDM, Fregapane G, Lercker G. 2009. Stability of the sensory quality of virgin olive oil during storage: An overview. Ital Food Beverage Technol 21: 389-406.

Boskou D. 2006. Olive oil - Chemistry and Technology. AOCS Press. https://doi.org/10.1159/000097916.

Caponio F, Bilancia MT, Pasqualone A, Sikorska E, Gomes T. 2005. Influence of the exposure to light on extra virgin olive oil quality during storage. Eur Food Res Technol 221: 92-98. https://doi.org/ 10.1007/s00217-004-1126-8.

Cinquanta L, Esti M, Notte ELa. 1997. Evolution of phenolic compounds in virgin olive oil during storage. $\mathrm{J} \mathrm{Am} \mathrm{Oil} \mathrm{Chem} \mathrm{Soc}$ 74: 1259-1264. https://doi.org/10.1007/s11746-997-0054-8.

Clodoveo ML, Delcuratolo D, Gomes T, Colelli G. 2007. Effect of different temperatures and storage atmospheres on Coratina olive oil quality. Food Chem 102: 571-576. https://doi.org/10.1016/j. foodchem.2006.05.035.

Del Caro A, Vacca V, Poiana M, Fenu P, Piga A. 2006. Influence of technology, storage and exposure on components of extra virgin olive oil (Bosana cv) from whole and de-stoned fruits. Food Chem 98: 311-316. https://doi.org/10.1016/j.foodchem.2005.05.075.

European Commission Regulation Eec/2568/91. 2003. Regulation $2568 / 91$ on the characteristics of olive oil and olive-residue oil and on relevant methods of analysis and later amendments. Annex II: determination of acidity value. Annex III: determination of peroxide index. Annex IX: spectrophotometric test of UV absorption. Off J Eur Communities 1248: 1-109.

Fregapane G, Lavelli V, Leon S, Kapuralin J, Salvador MD. 2006. Effect of filtration on virgin olive oil stability during storage. Eur J Lipid Sci Technol 108: 134-142. https://doi.org/10.1002/ ejlt.200501175.

García A, Brenes M, García P, Romero C, Garrido A. 2003. Phenolic content of commercial olive oils. Eur Food Res Technol 216: 520 525. https://doi.org/10.1007/s00217-003-0706-3.

Gómez-Alonso S, Mancebo-Campos V, Salvador MD, Fregapane G. 2007. Evolution of major and minor components and oxidation indices of virgin olive oil during 21 months storage at room temperature. Food Chem 100: 36-42. https://doi.org/10.1016/j. foodchem.2005.09.006.

Gutiérrez F, Fernández JL. 2002. Determinant parameters and components in the storage of virgin olive oil. Prediction of storage time beyond which the oil is no longer of "Extra" quality. J Agri Food Chem 50: 571-577. https://doi.org/10.1021/jf0102158.

Inarejos-Garcia AM, Androulaki A, Salvador MD, Fregapane G, Tsimidou MZ. 2009. Discussion on the objective evaluation of virgin olive oil bitterness. Food Res Intern 42: 279-284. https:// doi.org/10.1016/j.foodres.2008.11.009.

International Olive Council (IOC) Regulation. 2015a. COI/T.20/Doc. No.15/Rev.8. Sensory analysis of olive oil, method for the organoleptic assessment of virgin olive oil.

International Olive Council (IOC) Regulation. 2015b. COI/T.20/ Doc. No.19/Rev.3. Spectrophotometric investigation in the ultraviolet.

International Organization for Standardization. 2016. No. 662. Determination of the moisture and volatile matter. No. 662 .

Lavelli V, Fregapane G, Salvador MD. 2006. Effect of storage on secoiridoid and tocopherol contents and antioxidant activity of 
monovarietal extra virgin olive oils. J Agric Food Chem 54: 3002-3007.

Méndez AI, Falqué E. 2007. Effect of storage time and container type on the quality of extra-virgin olive oil. Food Control. https://doi. org/10.1016/j.foodcont.2005.12.012.

Montedoro G, Servili M, Baldioli M, Miniati E. 1992. Simple and hydrolyzable phenolic compounds in virgin olive oil. 1. Their extraction, separation, and quantitative and semiquantitative evaluation by HPLC. J Agric Food Chem 40: 1571-1576. https:// doi.org/10.1021/jf00021a019.

Morelló JR, Motilva MJ, Tovar MJ, Romero MP. 2004. Changes in commercial virgin olive oil (cv Arbequina) during storage, with special emphasis on the phenolic fraction. Food Chem 85: 357364. https://doi.org/10.1016/j.foodchem.2003.07.012.

Mulinacci N, Ieri F, Ignesti G, Romani A, Michelozzi M, Creti D, Innocenti M, Calamai L. 2013. The freezing process helps to preserve the quality of extra virgin olive oil over time: A case study up to 18 months. Food Res Intern 54: 2008-2015. https:// doi.org/10.1016/j.foodres.2013.03.052.
Okogeri O, Tasioula-Margari M. 2002. Changes occurring in phenolic compounds and alpha-tocopherol of virgin olive oil during storage. J Agric Food Chem 50: 1077-1080. https://doi.org/ 10.1021/jf010895e.

Ozkaya MT. 2016. Report for Hatay trade chamber on "Saurani" variety. (Unpublished).

Psomiadou E, Tsimidou M, Boskou D. 2000. Alpha-tocopherol content of Greek virgin olive oils. J Agric Food Chem 48: 1770-1775.

Rastrelli L, Passi S, Ippolito F, Vacca G, Simone F De. 2002. Rate of degradation of r-tocopherol, squalene, phenolics and polyunsaturated fatty acids in olive oil during different storage conditions. $J$ Agric Food Chem 5566-5570.

Romani ANR, Apucci CHL, Antini CLC, Eri FRI, Ulinacci NAM, Isioli FRV. 2007. Evolution of minor polar compounds and antioxidant capacity during storage of bottled extra virgin olive oil. J Agric Food Chem 55: 1315-1320.

Yorulmaz A. 2009. Türk Zeytinyaglarinin Fenolik, Sterol Trigliserit Yapilarini Belirlenmesi. Doktora Tezi, Ankara Üniversitesi Fen Bilimleri Enstitüsü. Turkey.

Cite this article as: Ghanbari Shendi E, Sivri Ozay D, Ozkaya MT, Ustunel NF. 2018. Changes occurring in chemical composition and oxidative stability of virgin olive oil during storage. $O C L$ 25(6): A602. 